
\title{
$\begin{array}{ll}\text { Research Square } & \begin{array}{l}\text { Preprints are preliminary reports that have not undergone peer review. } \\ \text { They should not be considered conclusive, used to inform clinical practice, }\end{array} \\ \text { or referenced by the media as validated information. }\end{array}$
}

\section{A Peripherally Inserted Central Catheter is as Useful as a Central Venous Catheter for Rapid Fluid Infusion}

Jun Maki

Kyushu University Hospital: Kyushu Daigaku Byoin https://orcid.org/0000-0001-8638-0646

\section{Makoto Sumie}

Kyushu University Faculty of Medicine Graduate School of Medical Science: Kyushu Daigaku Igakubu Daigakuin Igakukei Gakufu Daigakuin Igaku Kenkyuin

Tomoko Ide

Kyushu University Hospital: Kyushu Daigaku Byoin

\section{Masako Nagamatsu}

Kyushu University Hospital: Kyushu Daigaku Byoin

\section{Katsuyuki Matsushita}

Kyushu University Hospital: Kyushu Daigaku Byoin

\section{Kazuhiro Shirozu}

Kyushu University Hospital: Kyushu Daigaku Byoin

Midoriko Higashi ( $\nabla$ higashi.midoriko.976@m.kyushu-u.ac.jp )

https://orcid.org/0000-0002-1860-0747

\section{Ken Yamaura}

Kyushu University Faculty of Medicine Graduate School of Medical Science: Kyushu Daigaku Igakubu Daigakuin Igakukei Gakufu Daigakuin Igaku Kenkyuin

\section{Research Article}

Keywords: Peripherally inserted central catheter (PICC), central venous catheter (CVC), fluid infusion, rapid fluid infusion, blood transfusion

Posted Date: February 14th, 2022

DOI: https://doi.org/10.21203/rs.3.rs-1166325/v1

License: (c) (i) This work is licensed under a Creative Commons Attribution 4.0 International License. Read Full License 


\section{Abstract \\ Background}

Peripherally inserted central catheters (PICCs) have been widely used because of their low risk of mechanical complications associated with insertion compared with central venous catheters (CVCs). However, PICCs are not widely used for anesthetic management due to concerns regarding the measurement of central venous pressure (CVP) and rapid fluid infusion. The CVP measured via PICCs are reportedly as accurate as that measured via CVC, but the findings concerning rapid infusion are unclear. We therefore investigated the usefulness of a PICC as a rapid infusion route compared with a CVC.

\section{Methods}

The in-line pressure was measured in similar-sized double-lumen catheters - 4-Fr PICC (55, 45 and $35 \mathrm{~cm})$ and $17-G$ CVC (13 and $20 \mathrm{~cm}$ ) - at flow rates of saline decided using a roller pump system. We also examined the flow rate at an in-line pressure of $300 \mathrm{mmHg}$, which is the critical pressure at which hemolysis is considered to occur during blood transfusion.

\section{Results}

In-line pressures increased in proportion to the flow rate and catheter length in both the PICC and CVC. On comparing the 45-cm PICC and 20-cm CVC, the in-line pressures were higher in the PICC than in the CVC at a flow rate of $\leq 30 \mathrm{~mL} / \mathrm{min}$, although the opposite was true at a flow rate of $\geq 90 \mathrm{~mL} / \mathrm{min}$. Flow rates at an intra-circuit pressure of $300 \mathrm{mmHg}$ were not significantly different between the $45-\mathrm{cm}$ PICC and $20-\mathrm{cm}$ CVC.

\section{Conclusion}

A PICC can be used for rapid fluid infusion and blood transfusion, just like a CVC.

\section{Introduction}

Central venous catheters (CVCs) are used in perioperative management to monitor central venous pressure (CVP), administer cardiovascular agents and drugs irritating to veins, perform rapid fluid infusion and transfuse blood. However, because CVC insertion is associated with severe mechanical complications, the indications of CVCs are limited [1]. In contrast, the insertion of a peripherally inserted central catheter (PICC) carries a lower risk of mechanical complications [2] and is technically easier than CVC insertion. Although PICCs are widely used for parenteral nutrition, chemotherapy and long-term administration of antimicrobial agents, they have not been frequently used in perioperative management 
or acute care, as the accuracy of the CVP measured via a PICC and the reliability of PICCs as a route for rapid fluid infusion are unclear.

In hemodynamic monitoring, the CVP is measured via a CVC in $19 \%$ of non-cardiac surgeries lasting longer than 90 minutes, including 59\% of hepatobiliary surgeries [2]. In liver resection, a lower CVP has been shown to contribute to a reduced blood loss and shortened operating time and hospital stay, suggesting that CVP monitoring is useful for anesthetic management [3]. In kidney transplantation, CVP monitoring as a guide for intraoperative fluid management has been shown to contribute to a better graft function[4]. In both in vitro and clinical studies, the CVP measured via a PICC has been reported to be as accurate as that measured via a CVC $[5,6]$. The use of a PICC to monitor the CVP in anesthetic management and acute care is suggested to be possible.

In liver resection and kidney transplantation, CVCs are useful for rapid fluid infusion and blood transfusion, as well as CVP monitoring. However, PICCs are expected to be of greater use than CVCs, considering the risk of mechanical complications. In the management of sepsis, CVCs are also used frequently for rapid infusion as fluid resuscitation and CVP monitoring as an index of fluid responsiveness. PICCs are a potential choice in the management of sepsis, as they are safer than CVCs for patients with coagulopathy associated with sepsis [7]. However, whether or not PICCs can be used as a reliable route for rapid fluid infusion in emergency situations, such as massive hemorrhaging, has not yet been investigated.

In recent years, pressure-resistant PICCs suitable for injection of contrast media have become available. Thus, PICCs have potential utility as a rapid infusion route. Therefore, in the present study, we investigated the usefulness of PICCs as a rapid infusion route compared with CVCs.

\section{Methods}

The infusion circuit used to measure in-line pressure consisted of a blood transfusion set (TB-PU300L; TERUMO, Tokyo, Japan), the roller pump segment of a hemodialysis circuit (NS-1010-20; NIPRO, Osaka, Japan), and a three-way stopcock (L1-360FL; TOP, Tokyo, Japan). The blood transfusion set was connected to a $500-\mathrm{mL}$ bag of normal saline solution, and the 3-way stopcock was connected to the main lumen of a dual-lumen catheter (a PICC or CVC). The circuit was attached to a roller pump system for hemodialysis (MP-301; NIPRO). A pressure gauge (PG-208-103GP-S; NIDEC COPAL ELECTRONICS, INC., Tokyo, Japan) was placed at the three-way stopcock to measure the in-line pressure. The second lumen of the catheter was connected to a bag of normal saline via another blood transfusion set and perfused with $20 \mathrm{~mL} / \mathrm{h}$ normal saline using an infusion pump (TE-261; TERUMO). The catheter tip was then placed $10 \mathrm{~cm}$ under the surface of normal saline solution in a cup open in the atmosphere (Figure 1).

The flow rate of normal saline solution infused via the main lumen was regulated by the roller pump and increased and decreased stepwise by $10 \mathrm{~mL} / \mathrm{min}$ between 0 and $150 \mathrm{~mL} / \mathrm{min}$. After the equilibration period, the maximum in-line pressure was recorded at each flow rate. The in-line pressure at each flow rate was measured four times in each catheter. The catheters examined were as follows: 55-cm 4-Fr dual- 
lumen PICC (Power PICC ${ }^{\text {TM}}$; Bard Access Systems, Inc. Salt Lake City, UT, USA), and a 20- and 13-cm 17-G dual-lumen CVC (SMAC ${ }^{T M}$ plus; Cardinal Health, Dublin, OH, USA) (Table). After measurement, 55-cm PICC was cut to 45 and $35 \mathrm{~cm}$, in order.

The data were expressed as the average \pm standard error of the mean of values obtained from three catheters. The data were analyzed using a $t$-test or one-way analysis of variance with Tukey's test. A pvalue $<0.05$ was considered statistically significant.

\section{Results}

In-line pressures increased with the flow rate of normal saline at 0 to $150 \mathrm{~mL} / \mathrm{min}$ in both the PICC and CVC (Figure 2a, b). The maximum pressures in the 45-cm PICC and 20-cm CVC were $2084 \pm 62$ and 2523 $\pm 13 \mathrm{mmHg}$, respectively. In-line pressures increased in proportion to the length of catheter in both PICC and CVC (Figure 2a, b).

On comparing the 45-cm PICC and 20-cm CVC, the in-line pressures were higher in the 45-cm PICC at a low-flow range of 10 to $30 \mathrm{~mL} / \mathrm{min}$ but lower in the 45-cm PICC at a high-flow range of 90 to $150 \mathrm{~mL} / \mathrm{h}$ (Figure 2c). The flow rates when the in-line pressure was $\leq 300 \mathrm{mmHg}$ decreased in proportion to the catheter length in both the PICC and CVC (data not shown). The flow rate when the in-line pressure was $300 \mathrm{mmHg}$ was not significantly different between a 45-cm PICC and 20-cm CVC (Figure 3). The in-line pressure was not affected by repeated measurement (Additional information).

\section{Discussion}

In the present study, the flow rate and in-line pressures were positively correlated with the catheter length. On comparing a 45-cm PICC to a 20-cm CVC with a similar diameter, the in-line pressures were lower for the $20-\mathrm{cm} \mathrm{CVC}$ at a flow rate $<30 \mathrm{~mL} / \mathrm{min}$ but higher for rapid infusion at a flow rate $>80 \mathrm{~mL} / \mathrm{min}$. In addition, the flow rate at which the in-line pressure reached $300 \mathrm{mmHg}$, when hemolysis is expected to occur, did not differ markedly between the 45-cm PICC and 20-cm CVC.

Regarding the relationship between the flow rate and in-line pressure, longer catheters have a higher inline pressure than shorter ones. In our previous report concerning the relationship between the flow rate and in-line pressure using a peripheral venous catheter, there was a positive correlation between the catheter length and in-line pressure with an 18-G peripheral venous catheter, which has same diameter as the lumen of the PICC used in the present study. The in-line pressure was approximately $300 \mathrm{mmHg}$ at a flow rate of $150 \mathrm{~mL} / \mathrm{min}(9000 \mathrm{~mL} / \mathrm{h})$ [8]. The length of the peripheral venous catheter was $4.8 \mathrm{~cm}$ in the previous study, while the lengths of the CVC and PICC with the same diameter in the present study were 13 and $20 \mathrm{~cm}$ and 35,45 and $55 \mathrm{~cm}$. In each catheter, the in-line pressure increased to $1745-2523 \mathrm{mmHg}$ as the catheter length was increased. However, in the present study, we confirmed that repeated infusions at an in-line pressure of $\geq 2000 \mathrm{mmHg}$ did not affect the flow rate or in-line pressure using a pressure- 
resistant PICC or CVC. These results suggest that there is no issue with performing repeated highpressure infusion.

Compared with rapid infusion from a peripheral venous catheter, the flow rate was limited when rapid intravenous infusion was performed with a PICC. However, a pressure-resistant PICC can withstand rapid intravenous infusion of $150 \mathrm{~mL} / \mathrm{min}(9000 \mathrm{~mL} / \mathrm{h})$, which is clinically sufficient. The maximum pressure of a clinical pressurized rapid infusion device is limited to $300 \mathrm{mmHg}$, and it has been reported that in-line pressure is increased to about $600 \mathrm{mmHg}$ during manual rapid infusion using a piston syringe [9]. In the present study, a pressure-resistant PICC was able to withstand a higher pressure than exerted with these methods, suggesting that a pressure-resistant PICC can be safely used for rapid infusion.

On comparing a 45-cm PICC with a 20-cm CVC, which are usually used clinically, the PICC, which was longer than the CVC, was expected to have a higher in-line pressure with the same flow rate provided the catheter diameter was the same. However, in actuality, the in-line pressure of the PICC was higher than that of the CVC at a low flow rate, whereas the in-line pressure of the PICC at a high flow rate was significantly lower than that of the CVC. This is considered to be due to the lumen partition wall of the double-lumen tube used in this study. In CVCs, the luminal septum does not move, whereas in pressureresistant PICCs, the shape of the catheter lumen changes according to the in-line pressure, which expands the effective inner diameter of the catheter.

Regarding red blood cell products, hemolysis reportedly occurs under pressures exceeding $300 \mathrm{mmHg}$ [10]. Thus, rapid transfusion using a pressurized rapid transfusion device was performed at a maximum internal pressure of $300 \mathrm{mmHg}$. In the present study, the rate of saline administration that resulted in an in-line pressure of $300 \mathrm{mmHg}$ did not differ between the 45-cm PICC and 20-cm CVC and was comparable to $30 \mathrm{~mL} / \mathrm{min}(1800 \mathrm{~mL} / \mathrm{h})$. Therefore, the PICC can be used as a transfusion route as well as the CVC in case of rapid transfusion due to massive bleeding. If the flow rate is higher than this, transfusion should be performed through a larger venous route, such as a peripheral venous catheter or sheath.

Several limitations associated with the present study warrant mention. First, the data in the present study were obtained from an in vitro study. Thus, the in-line pressure may be influenced by the intravascular position and resistance of vasculature and may actually be much higher than the result shown here. Second, because the in-line pressure was not measured using red blood cells, the usefulness of a PICC in blood transfusion has not been confirmed.

\section{Conclusion}

The flow rate and in-line pressures were positively correlated with catheter length. However, PICCs are lower at high flow rate than CVCs and may be superior to CVCs with regard to rapid infusion. In addition, the flow rate at which the in-line pressure reaches $300 \mathrm{mmHg}$, when hemolysis is expected to occur, was not markedly different between the PICC and CVC. PICCs may thus be as useful as CVCs and a safer device in surgery and acute care. 


\section{Abbreviations}

CVCs: Central venous catheters

CVP: central venous pressure

PICCs: peripherally inserted central catheter

\section{Declarations}

\section{Ethics approval and consent to participate}

Not applicable.

\section{Consent for publication}

Not applicable.

\section{Availability of data and materials}

The datasets used and/or analyzed during the current study are available from the corresponding author on reasonable request.

\section{Conflicts of interest/Competing interests}

There are no relevant conflicts of interest.

\section{Funding}

This study was supported by departmental funding only.

\section{Availability of data and material}

All data generated or analyzed during this study are included in this published article.

\section{Code availability}

Not applicable

\section{Authors' contributions}

All authors contributed to the study conception and design. The material preparation, data collection and analysis were performed by Jun Maki, Makoto Sumie and Katsuyuki Matsushita. The first draft of the manuscript was written by Jun Maki, and all authors commented on previous versions of the manuscript. All authors read and approved the final manuscript. 
Acknowledgments

The authors thank Dr. Brian Quinn for the careful reading and editing of the manuscript.

\section{References}

1. Moureau N, Chopra V: Indications for peripheral, midline and central catheters: summary of the MAGIC recommendations. Br J Nurs 2016, 25(8):S15-24.

2. Kim YO, Chung CR, Gil E, Park CM, Suh GY, Ryu JA: Safety and feasibility of ultrasound-guided placement of peripherally inserted central catheter performed by neurointensivist in neurosurgery intensive care unit. PLoS One 2019, 14(5):e0217641.

3. Moggia E, Rouse B, Simillis C, Li T, Vaughan J, Davidson BR, Gurusamy KS: Methods to decrease blood loss during liver resection: a network meta-analysis. Cochrane Database Syst Rev 2016, 10:CD010683.

4. Wagener G, Bezinover D, Wang C, Kroepfl E, Diaz G, Giordano C, West J, Kindscher JD, Moguilevitch M, Nicolau-Raducu R et al: Fluid Management During Kidney Transplantation: A Consensus Statement of the Committee on Transplant Anesthesia of the American Society of Anesthesiologists. Transplantation 2021, 105(8):1677-1684.

5. Latham HE, Dwyer TT, Gregg BL, Simpson SQ: An in vitro study comparing a peripherally inserted central catheter to a conventional central venous catheter. no difference in static and dynamic pressure transmission. BMC Anesthesio/ 2010, 10:18.

6. Sanfilippo F, Noto A, Martucci G, Farbo M, Burgio G, Biasucci DG: Central venous pressure monitoring via peripherally or centrally inserted central catheters: a systematic review and meta-analysis. $J$ VasC Access 2017, 18(4):273-278.

7. Potet J, Arnaud FX, Thome A, Weber-Donat G, Konopacki J, Bouzad C, Kervella Y, Erauso T, Garcia G, Evelyne $\mathrm{P}$ et al: Peripherally inserted central catheter placement in patients with coagulation disorders: A retrospective analysis. Diagn Interv Imaging 2015, 96(11):1147-1151.

8. Higashi M, Yamaura K, Matsubara Y, Fukudome T, Hoka S: In-line pressure within a HOTLINE(R) Fluid Warmer, under various flow conditions. J Clin Monit Comput 2015, 29(2):301-305.

9. Smart CM, Primrose CW, Peters AL, Speirits EJ: The properties of an improvised piston pump for the rapid delivery of intravenous fluids. Anaesthesia 2014, 69(2):111-117.

10. De Villiers WL, Murray AA, Levin Al: Expediting red blood cell transfusions by syringing causes significant hemolysis. Transfusion 2017, 57(11):2747-2751.

\section{Tables}

Table. Details of a PICC and CVCs.

PICC, peripherally inserted central catheter; CVC, central venous catheter; OD, outer catheter diameter; ID inner catheter diameter 


\begin{tabular}{cccccc} 
Catheters & $\begin{array}{c}\text { Number of } \\
\text { lumen }\end{array}$ & OD $(\mathrm{mm})$ & Length $(\mathrm{cm})$ & $\begin{array}{c}\text { ID of main } \\
\text { lumen }(\mathrm{G})\end{array}$ & $\begin{array}{c}\text { ID of second } \\
\text { lumen }(\mathrm{G})\end{array}$ \\
\hline 4Fr PICC & 2 & 1.33 & $55(45,35)$ & 19 & 21 \\
17G CVC & 2 & 1.35 & 13,20 & 18 & 21
\end{tabular}

\section{Figures}

\section{Figure 1}

A schematic illustration of infusion circuit for measuring in-line pressure.

The circuit to infuse normal saline consisted of a blood transfusion set, a roller pump system and a threeway stopcock connected to the main lumen of a catheter. A pressure gauge was connected to the stopcock. The second lumen of the catheter was perfused with normal saline using an infusion pump.

\section{Figure 2}

Relationships between the flow rates and in-line pressure.

(a) Triangles and (b) circles show in-line pressures at indicated flow rates in 55-, 45- and 35-cm peripherally inserted central catheters (PICCs) and 20- and 13-cm central venous catheters (CVCs). (c) Inline pressures at the indicated flow rates in the 45-cm PICC (gray triangles) were compared with those in CVCs (filled circles). Data are shown as the average \pm SEM, and significant differences are represented by $*(p<0.05)$.

\section{Figure 3}

A comparison of the flow rates at an in-line pressure of $300 \mathrm{mmHg}$.

The flow rates at an in-line pressure of $300 \mathrm{mmHgwere}$ compared between a 20-cm central venous catheter (CVC) and 45-cm peripherally inserted central catheter (PICC). The flow rates were not significantly different between these catheters $(p<0.05)$. Data are shown as the average \pm SEM. n.s., not significantly different. 


\section{Supplementary Files}

This is a list of supplementary files associated with this preprint. Click to download.

- Al.tiff 